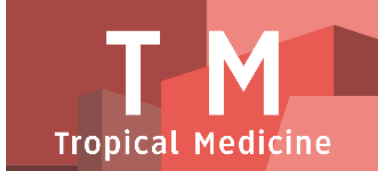

PAPER - OPEN ACCESS

Formulasi Tablet Hisap Ekstak Etanol Daun Randu (Ceiba Pentandra L. Gaertn) Menggunakan Carboxy Methyl Cellulose (CMC) Sebagai Bahan Pengikat Dengan Metode Granulasi Basah

$\begin{array}{ll}\text { Author } & : \text { T. Ismanelly Hanum } \\ \text { DOI } & : 10.32734 / \text { tm.v1i3.260 } \\ \text { Electronic ISSN } & : 2623-0542 \\ \text { Print ISSN } & : 2623-0550\end{array}$

Volume 1 Issue 3-2018 TALENTA Conference Series: Tropical Medicine (TM)

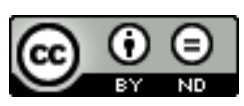

This work is licensed under a Creative Commons Attribution-NoDerivatives 4.0 International License.

Published under licence by TALENTA Publisher, Universitas Sumatera Utara
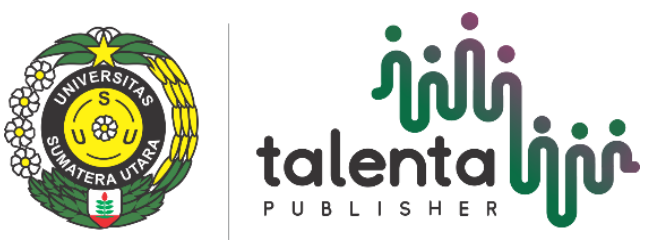


\title{
Formulasi Tablet Hisap Ekstak Etanol Daun Randu (Ceiba Pentandra L. Gaertn) Menggunakan Carboxy Methyl Cellulose (CMC) Sebagai Bahan Pengikat Dengan Metode Granulasi Basah
}

\author{
T. Ismanelly Hanum ${ }^{\mathrm{a}^{*}}$, Siti Indah Lestari ${ }^{\mathrm{b}}$ \\ ${ }^{a b}$ Departemen Teknologi Farmasi, Fakultas Farmasi,Universitas Sumatera Utara, Medan 20155 \\ ${ }^{b}$ FMIPA, Universitas Muslim Nusantara, Medan \\ isma_nelly@usu.ac.id
}

\begin{abstract}
Abstrak
Daun randu (Ceiba pentandra L.Gaertn) merupakan salah satu tumbuhan yang mengandung tannin dan flavonoid yang mempunyai aktivitas sebagai antibakteri. Ekstrak etanol daun randu mempunyai aktivitas sebagai anti bakteri yang dapat menghambat pertumbuhan bakteri pada mulut. Tujuan dari penelitian ini adalah untuk memformulasikan ekstrak daun randu dalam bentuk sediaan tablet hisap dengan menggunakan Carboxy Methyl Cellulose (CMC) sebagai bahan pengikat dengan metode graulasi basah. Pembuatan ekstrak etanol daun randu dengan metode maserasi, pembuatan tablet hisap, pengujian granul dan evaluasi tablet pada variasi konsentrasi $\mathrm{cmc} 2 \%, 3 \%$, dan $4 \%$..

Skrining fitokimia serbuk dan ekstrak daun randu mengandung metabolit sekunder golonganta tanin, saponin, flavonoid, glikosida dan steroid. Hasil pemeriksaan karakterisasi serbuk daun randu diperoleh kadar air 7,32\%, kadar abu total 9,05\%, kadar abu yang tidak larut asam 0,31\%, kadar sari larut dalam air $27,01 \%$ dan kadar sari larut dalam etanol $30,80 \%$. Hasil evaluasi granul menunjukkan bahwa semua formula telah memenuhi persyaratan evaluasi granul. Hasil evaluasi tablet menunjukkan bahwa dari ketiga formula yang dibuat semua formula memenuhi syarat kecuali pada uji kekerasan tablet pada formula $2 \%$ tablet hisap memiliki kekerasan $3,5 \mathrm{~kg}$.

Ekstrak etanol daun randu (Ceiba pentandra L.Gaertn) dapat dibuat menjadi sediaan tablet hisap menggunakan CMC sebagai bahan pengikat dengan metode granulasi basah.
\end{abstract}

Kata kunci : Ekstrak daun randu, tablet hisap, CMC.

\begin{abstract}
Silk-cotton leaves (Ceiba pentandraL.Gaertn) isaplant containing tannins and flavonoids that have activity as an antibacterial. Ethanol extract of the leaf has activity as anti bacterium which can inhibit the growth of bacteria in the mouth. The purpose of this study was to formulate the extract of the leaf in the form of troches tablets using Carboxy Methyl Cellulose (CMC) as a binder with the method of wet granulation.

Preparation of ethanol extract of the leaf with maceration method, preparation of troches tablet,granule test and tablet evaluation on concentration variation of $\mathrm{cmc} 2 \%, 3 \%$, and $4 \%$.

Phytochemical screening both of powder and extract showed that silk cotton leaves contain secondary metabolites of tannins, saponins, flavonoids, glycosides,and steroids. The results of characterization examination of silk cotton leaves powder obtained moisture content $7,32 \%$, total ash content $9,05 \%$, acid unsaturated ash content $0,31 \%$, water-soluble extract content $27,01 \%$ and soluble extract content in ethanol $30,80 \%$. The granule evaluation results indicate that all the formulas have met the requirements of granule evaluation. The results of the troches evaluation showed that of the three formulas made all the formulas met the requirements except on the tablet hardness test on the formula $2 \%$ troches has a hardness of $3.5 \mathrm{~kg}$.

Silk cotton leaves ethanolic extract can be formulated in troches using CMC as a binder with the method of wet granulation.
\end{abstract}


Keywords: silk-cotton leaves extract, troches, CMC

\section{Pendahuluan}

Pemanfaatan tumbuhan sebagai obat tradisional dibanding obat sintetik disebabkan oleh keanekaragaman tumbuhan di alam Indonesia dan obat tradisional lebih murah serta memiliki efek samping yang relatif lebih ringan dibanding obat sintetik [1].

Secara empiris masyarakat Indonesia memanfaatkan daun randu sebagai obat kudis, obat batuk, disentri, menurunkan panas, diare, radang usus dan amandel [2]. Daun randu mengandung fenol, glikosida, saponin, tanin, steroid/terpenoid dan flavonoid [3\}. Saponin diketahui dapat meningkatkan aliran darah kapiler [4], serta flavonoid yang mempunyai aktivitas sebagai anti bakteri [5]. Beberapa penelitian yang telah dilakukan terhadap daun randu diantaranya sebagai sediaan penumbuh rambut [6], sebagai anti diare [2] dan sebagai anti bakteri [5]

Daun randu sendiri mempunyai rasa yang tidak enak dan kelat, sehingga untuk menutupi rasa yang tidak enak dan untuk memberi kenyamanan pada saat dikonsumsi, maka perlu dibuat sediaan dari ekstrak daun randu yang mempunyai rasa yang enak dan yang bisa melarut perlahan-lahan pada mulut sehingga efek lokal antiseptik yang diharapkan dapat lebih efektif bekerja sehingga pilihan yang tepat adalah membuat sediaan tablet hisap.

Bentuk tablet hisap lebih disukai karena terdapat bahan pemanis dan sesuai untuk konsumen yang mempunyai kesulitan dalam menelan, karena cukup dengan mengisapnya pelan-pelan, tidak diperlukan air minum sehingga lebih mudah dalam penggunaannya [7]

Bahan pengikat yang digunakan dalam pembuatan tablet hisap daun randu adalah Carboxy Methyl Cellulose(CMC). CMC merupakan kelompok bahan pengikat polimer, berfungsi memberi daya adhesi pada massa serbuk serta untuk menambah daya kohesi yang telah ada pada bahan pengisi. Dengan demikian cmc diharapkan mempunyai tingkat kekerasan tablet yang tinggi, sehingga sesuai diaplikasikan sebagai tablet hisap [8].

Metode yang digunakan dalam pembuatan tablet hisap ini adalah metode granulasi basahkarena zat aktif berupa ekstrak maka dibuat menjadi granul sehingga dapat memperbaiki sifat alirnyadan memiliki sifat granul yang kompak [8].

Berdasarkan uraian tersebut, peneliti memformulasikan dan mengevaluasi sediaan tablet hisap dari ekstrak daun randu dengan metode granulasi basah menggunakan variasi cmc sebagai bahan pengikat.

\section{Bahan dan Metode}

Bahan yang digunakan dalam penelitian ini adalah daun randu (Ceiba pentandra L. Gaertn). Semua bahan kimia diperoleh dari Bratachem yaitu aquadest, etanol 96\%, toluen, kloroform, merkuri (II) klorida, kalium iodida, natrium hidroksida, iodium, bismuth (III) nitrat, besi (III) klorida, asam nitrat, asam asetat anhidrat, asam sulfat pekat,asam sulfat encer, asam klorida pekat, asam klorida encer, timbal asetat, alfa naftol,serbuk magnesium,isopropanol, amil alkohol, n-heksan, kloralhidrat, cmc, talkum, asam sitrat anhidrat, laktosa monohidrat, sukrosa,dan esens apel.

\subsection{Alat}

Alat yang digunakan dalam penelitian ini adalah lemari pengering, alat-alat gelas laboratorium, blender, rotary evaporator, alat destilasi azeotrop, heaating mantle, termometer, neraca analitik, oven, corong alir, alat pencetak tablet, strongcob hardness, friabilator, dan disintegration tester.

\subsection{Metode Penelitian}

Skrining fitokimia ekstrak dan serbuk daun randu serta karakterisasi serbuk dilakukan menurut prosedur pada Materia Medika [9]

\subsection{Pembuatan Ekstrak Etanol Daun Randu}

Pembuatan ekstrak daun randu (Ceiba pentandra L.Gaertn) dengan metode maserasi menggunakan pelarut etanol $96 \%[10]$ 


\subsection{Formula Tablet Hisap Ekstrak Etanol Daun Randu}

Tabel 1. Formula Tablet Hisap Ekstrak Etanol Daun Randu

\begin{tabular}{lllll}
\hline \multirow{2}{*}{ No } & Bahan & Formula & & \\
\cline { 3 - 4 } 1 & & $\mathrm{~A}$ & $\mathrm{~B}$ & $\mathrm{C}$ \\
2 & Ekstrak daun randu (mg) & 100 & 100 & 100 \\
3 & Manitol (mg) & 175,625 & 173,125 & 170,625 \\
4 & Laktosa monohidrat (mg) & 175,625 & 173,125 & 170,625 \\
5 & Talkum (mg) (Bahan pengikat) & 2 & 3 & 4 \\
6 & Asam sitrat anhidrat (mg) & 25 & 25 & 25 \\
7 & Sukrosa (mg) & 12,5 & 12,5 & 1,25 \\
8 & Minyak Apel & 1,25 & 1,25 & 3 \\
\multicolumn{2}{l}{ Total (mg) } & 3 & 3 & 500 \\
\hline
\end{tabular}

\subsection{Pembuatan Tablet Hisap}

Tablet hisap dibuat dengan metode granulasi basah. Setelah ekstrak kental mengering dicampurkan dengan manitol, laktosa monohidrat dan asam sitrat anhidrat dalam lumpang gerus homogen, lalu ditambah ekstrak daun randu dicampur sampai homogen (campuran 1). Setelah itu ditambahkan bahan pengikat cmc yang telah membentuk massa yang kental, sedikit demi sedikit hingga diperoleh massa yang dapat dikepal. Massa diayak dengan ayakan mesh no. 8 , kemudian dikeringkan di lemari pengering pada suhu $40-50^{\circ} \mathrm{C}$ selama 24 jam. Massa kering diayak kembali dengan ayakan mesh no.12, ditambahkan talkum dan sukrosa campur hingga homogen dan dilakukan evaluasi granul sebelum dikempa. Granul dengan bobot sekitar $500 \mathrm{mg}$ pada tekanan tertentu dicetak dengan alat pencetak tablet.

\subsection{Evaluasi granul}

\subsubsection{Laju Alir}

Sejumlah granull ( \pm 75 gram) yang akan dicetak dimasukkan ke dalam corong alir, kemudian dialirkan hingga seluruhnya mengalir dan ditentukan waktu alir mulai dari granul mengalir sampai seluruhnya mengalir keluar[11].

\subsubsection{Sudut Diam}

Sejumlah sampel ( $\pm 25 \mathrm{gram})$, dimasukkan ke dalam corong alir, lalu permukaannya diratakan. Sampel dibiarkan mengalir dan sudut reposa ditentukan dengan mengukur sudut kecuraman bukit dari perbandingan tinggi bukit $(\mathrm{cm})$ dan jari-jari alas bukit (cm) yang dihitung sebagai berikut [11]:

\subsubsection{Indeks Tap}

Sejumlah \pm 25 gram sampel dimasukkan kedalam gelas ukur $25 \mathrm{ml}$, lalu diukur volumenya $\left(\mathrm{V}_{0}\right)$. kemudian dilakukan tap hingga hasil penurunan granul stabil [11].

\subsection{Evaluasi Tablet}

\subsubsection{Penampilan Fisik}

Evaluasi dilakukan untuk melihat penampilan umum tabletdan parameter-parameter seperti bentuk, warna, bentuk permukaan, serta deteksi adanyacacat fisik [11] 


\subsubsection{Keseragaman Ukuran}

Keseragaman ukuran, dan keseragaman bobot tablet dilakukan menurut Farmakope Idonesia Edisi III [10]

\subsubsection{Kekerasan Tablet}

Alat penguji kekerasan tablet yang digunakan adalah Strongcob hardness. Caranya adalah satu buah tablet diletakkan tegak lurus pada alat, kemudian dilihat pada tekanan berapa tablet tersebut pecah [8]

\subsubsection{Friabilitas}

Sebanyak dua puluh tablet dimasukkan ke dalam alatFriabilitor tester dengan kecepatan 25 rpm selama 4 menit (100 kali putaran). Kemudian keluarkan tablet, bersihkan dari debu dan ditimbang kembali. Hitung selisih berat sebelum dan sesudah perlakuan [8]

\subsubsection{Waktu Hancur}

Uji waktu hancur tablet dilakukan menurut Farmakope Edisi III [10,11] dan juga dilakukan langsung oleh responden sekaligus pada saat dilakukan uji tanggapan rasa.

\subsubsection{Uji Kesukaan}

Formula tablet hisap dicoba oleh tiga puluh responden (15 wanita dan 15 pria) dengan umur responden 20-35 tahun, lalu responden memberi pendapat terhadap penampilan, rasa dan aroma dari formula yang dibuat serta lamanya tablet hisap larut di dalam mulut.

\section{Hasil Dan Pembahasan}

Hasil evaluasi granul dan tablet hisap dari ekstrak daun randu dapat dilihat pada Tabel 2 :

Tabel 2.Hasil evaluasi granul dan tablet hisapekstrak daun randu

\begin{tabular}{ccccccc}
\hline \multirow{2}{*}{$\begin{array}{c}\text { Formula variasi } \\
\text { cmc }\end{array}$} & $\begin{array}{c}\text { Laju Alir } \\
\text { (Detik) }\end{array}$ & Sudut Diam $\left({ }^{\circ}\right)$ & Indeks Tap (\%) & Kekerasan (Kg) & Friabilitas (\%) & $\begin{array}{c}\text { Waktu Hancur } \\
(\text { menit) }\end{array}$ \\
\cline { 2 - 8 } $2 \%$ & 4,37 & 26,38 & $4 \%$ & 3,5 & 0,22 & 7 \\
$3 \%$ & 4,43 & 27,73 & $4,67 \%$ & 5 & 0,11 & 10 \\
$4 \%$ & 5,23 & 27,39 & $4,67 \%$ & 6 & 0,04 & 20 \\
\hline
\end{tabular}

Berdasarkan hasil evaluasi laju alir granul pada Tabel 2, ketiga formula dengan variasi konsentrsi cmc memenuhi syarat laju alir yaitu < 10 detik. Pengujian laju alir sangat penting karena berhubungan dengan keseragaman pengisian ruang cetakan yang akan mempengaruhi keseragaman bobot dan pada akhirnya akan mempengaruhi keseragaman kandungan zat aktif [11]

Sudut diam yang dihasilkan dari ketiga formula termasuk dalam kategori istimewa $\left(25^{\circ}\right.$ $30^{\circ}$ ). Semakin kecil sudut diam yang terbentuk maka semakin baik sudut diamnya., Sifat alir yang baik akan membuat pengisian die terpenuhi secara merata sehingga keseragaman bobot tablet tidak menyimpang [11].

Hasil indeks tap yang dimiliki oleh ketiga formula memenuhi syarat karena syarat indeks kompresibilitas yaitu $<20 \%$, hal ini menunjukkan bahwa massa tablet memiliki sifat untuk membentuk massa tablet yang stabil dan kompak bila diberi tekanan [11]

Evaluasi penampilan fisik tablet hisap dari ketiga formula umumnya berbentuk bulat datar, berwarna hijau kehitaman,wangi apel, dan berasa asam manis.Rasa manis yang dihasilkan berasal dari laktosa, manitol, dan sukrosa sedangkan rasa asam didapat dari penambahan asam sitrat anhidrat. 
Tabel 3. Data Keseragaman Ukuran dan Bobot Tablet Hisap

\begin{tabular}{lllll}
\hline \multirow{2}{*}{$\begin{array}{l}\text { Formula variasi } \\
\mathrm{cmc}\end{array}$} & \multicolumn{3}{l}{ Keseragaman Ukuran } & Keseragaman Bobot \\
\cline { 2 - 5 } $2 \%$ & Diameter $(\mathrm{mm})$ & Tebal $(\mathrm{mm})$ & Kolom A & Kolom B \\
$3 \%$ & 3 & Tablet $<5 \%$ & Tablet $<10 \%$ \\
$\mathbf{4 \%}$ & 13 & 3 & Tablet $<5 \%$ & Tablet $<10 \%$ \\
& 13 & 3 & Tablet $<5 \%$ & Tablet $<10 \%$ \\
\hline
\end{tabular}

Berdasarkan hasil evaluasikeseragaman ukuran tablet (Tabel 3) menunjukkan keseragaman tablet yang memenuhi syarat, dimana diameter tablet tidak lebih dari 3 kali dan tidak kurang dari 1 1/3 tebal tablet [10].

Berdasarkan evaluasi keseragaman bobot tidak lebih dari 2 tablet yang menyimpang lebih besar 5\% (kolom A) dan tidak ada satu tablet pun yang menyimpang lebih besar dari 10\% (kolom B) [10]. Sehingga dapat dinyatakan bahwa ketiga formulasi memenuhi persyaratan keseragaman bobot.

Kekuatan tablet ditentukan dengan cara mengukur kekerasan dan friabilitas tablet. Syarat kekerasan tablet adalah 4-10 Kg [8]. Hasil kekerasan tablet ditunjukkan pada Tabel 2 pada formula $2 \%$ tidak memenuhi syarat kekerasan tablet sedangkan pada formula $3 \%$ dan $4 \%$ memenuhi syarat kekerasan tablet. Hal tersebut disebabkan pada formula $2 \%$ bahan pengikat yang digunakan memiliki konsentrasi yang kecil sehingga kekerasan tablet pun rendah, sehingga dapat disimpulkan bahwa semakin tinggi konsentrasi pengikat yang digunakan maka kekerasannya pun akan semakin meningkat. Kekerasan berguna sebagai metode pengontrolan fisik tablet selama proses pembuatan [8]

Uji friabilitas tablet dilakukan untuk mengetahui ketahanan tablet terhadap guncangan yang terjadi selama proses pembuatan, pengemasan dan pendistribusian. Syarat friabilitas tablet adalah kurang dari 1\% [8]. Hasil uji friabilitas menunjukkan bahwa ketiga formula memenuhi syarat uji friabilitas. Diantara ketiga formula tersebut, friabilitas yang paling besar dimiliki formula $2 \%$ yaitu $0,22 \%$. Hal tersebut dikarenakan pada formula $2 \%$ bahan pengikat yang digunakan konsentrasinya paling kecil, sehingga ketahanan tablet terhadap guncangan pun rendah.

Waktu hancur merupakan parameter yang sangat penting pada tablet hisap. Tablet hisap diharapkan memiliki waktu larut antara 30 menit atau kurang [8]. Hasil uji waktu larut menunjukkan bahwa semakin tinggi konsentrasi bahan pengikat cmc maka semakin lama pula waktu larutnya. Hal ini dikarenakan sifat dari cmc yang memiliki kecenderungan mengeras pada penyimpanan, sehingga semakin tinggi konsentrasi $\mathrm{cmc}$ sebagai bahan pengikat maka akan meningkatkan kekompakan massa tablet sehingga akan lebih lama terkikis atau terlarut.

Uji kesukaan tablet hisapketiga formula diujikan kepada30 responden untuk memberikan pendapatnya mengenai penampilan, rasa dan aroma. Berdasarkan hasil uji kesukaan sebanyak 21 responden suka dengan penampilan tablet hisap dan tidak ada satupun responden yang tidak menyukai penampilan tablet hisap (Gambar 1)
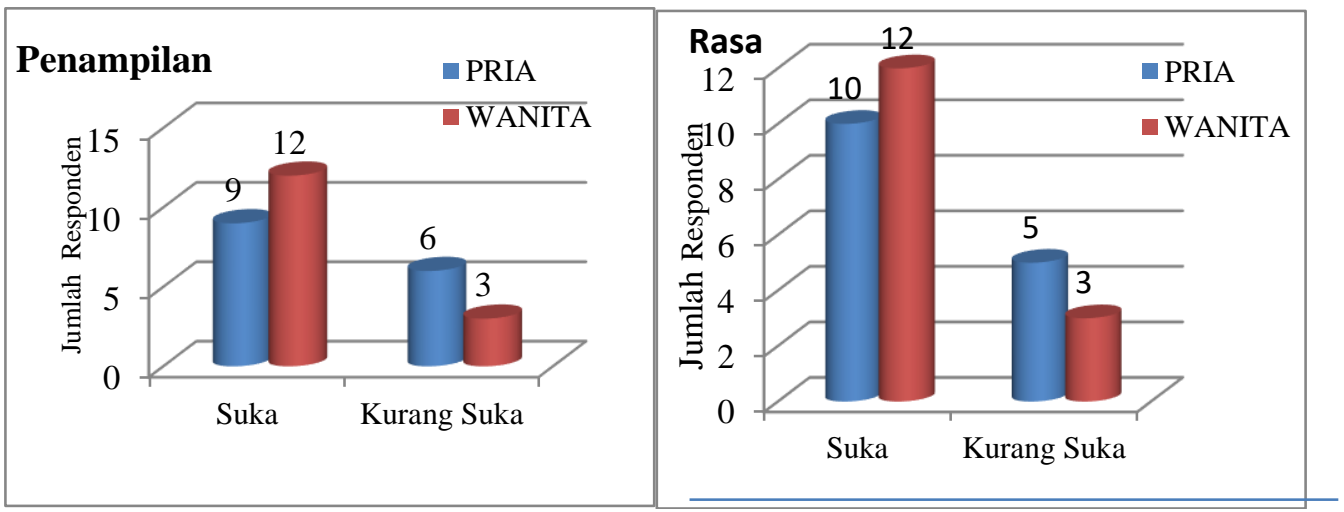

Gambar 1. Grafik Uji Kesukaan Responden Terhadap Penampilan dan Rasa Sediaan Tablet Hisap Ekstrak Etanol daun Randu

Untuk uji kesukaan terhadap rasa tablet hisap sebagian besar responden suka dengan rasa tablet hisap hal ini disebabkan kombinasi rasa asam manis dari manitol, laktosa, sukrosa dan asam sitrat anhidrat (Gambar 1)

Pada formulasi tablet hisap ditambahkan flavouring agent yaitu pewangi apel, hal ini dilakukan karena dikhawatirkan aroma atau bau dari ekstrak daun randu masih dapat tercium sehingga dapat mengurangi kenyamanan 
responden. Sebanyak 12 responden sangat suka dengan aroma tablet hisap, 18 responden suka dengan aroma tablet hisap dan tidak ada satu responden pun yang tidak suka dengan aroma tablet hisap.

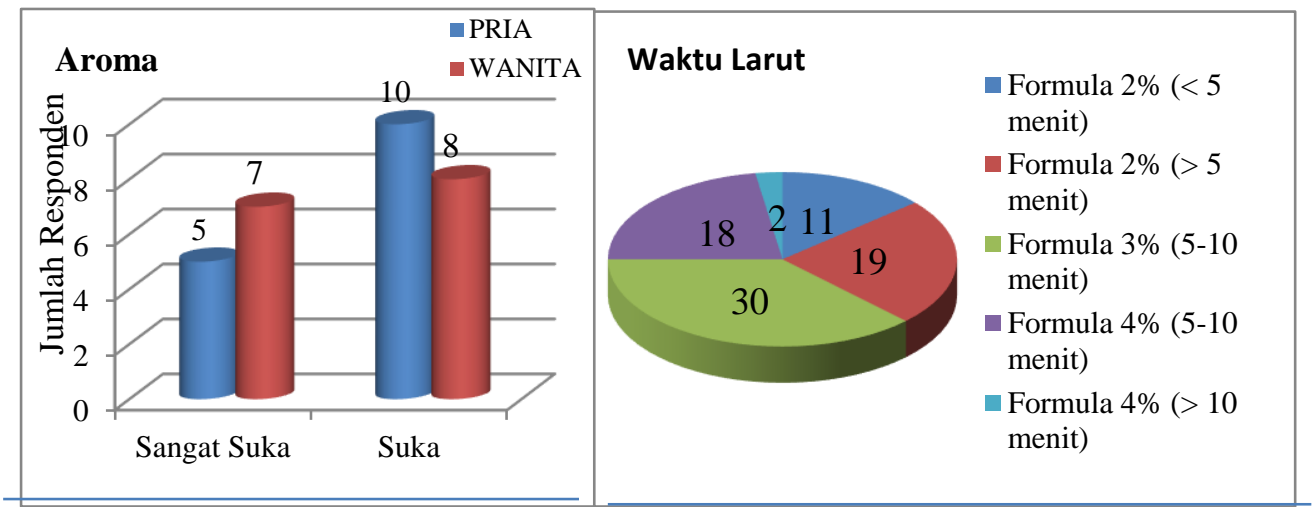

Gambar 2. Grafik Uji Kesukaan Responden Terhadap Aroma dan Waktu Larut Sediaan Tablet Hisap Ekstrak Etanol Daun Randu

Pada uji kesukaan, ketiga formula memiliki penampilan, rasa dan aroma yang dapat diterima oleh responden, serta formula yang memberikan hasil waktu larut yang paling baik adalah formula 3\% yaitu sekitar 5-10 menit. Dari hasil penelitian ini dapat diketahui bahwa formula 3\% dan formula $4 \%$ yang menghasilkan formula yang paling baik dan memenuhi syarat evaluasi granul dan evaluasi tablet.

\section{Kesimpulan}

Ekstrak etanol daun randu (Ceiba pentandra L.Gaertn) dapat dibuat menjadi sediaan tablet hisap menggunakan CMC sebagai bahan pengikat dengan metode granulasi basah.

Formulasi tablet hisap dari ekstrak daun randu (Ceiba pentandra L.Gartn) memenuhi persyaratan uji evaluasi granul pada ketiga formula dan memenuhi persyarataan uji evaluasi tablet pada formula $3 \%$ dan $4 \%$, serta memenuhi persyaratan uji kesukaan waktu larut dalam rongga mulut pada ketiga formula.

\section{Ucapan Terima Kasih}

Ucapan terima kasih kepada yayasan perintis atas bantuan dana yang diberikan sehinga selesainya penelitian ini.

\section{Daftar Pustaka}

[1] Nurwaini, S., dan Wikantyasning, E.R. 2011. Formulasi Tablet Hisap Ekstrak Daun Kemnagi (Ocimum sanctumL.) Pengaruh Kadar Natrium Karboksi Metil Selulosa Sebagai Bahan Pengikat Terhadap Sifat Fisik Tablet. Jurnal Farmasi. Surakarta: Fakultas Farmasi Universitas Muhammadiyah Surakarta.

[2] Anas, Y., Fithria, R.F., Purnamasari, Y.A., Ningsih, K.A., Noviantoro, A.G., dan Suharjono. 2014. Aktivitas Antidiare Ekstrak Etanol Daun Randu (Ceiba pentandra L. Gaertn) Pada Mencit Jantan Balur Balb/C. Jurnal Farmasi. Semarang : Fakultas Farmasi Universitas Walud Hasyim Semarang.

[3] Elela, M.E.A., Orabi, M.A.A., Abdelkader, M.S.A., dan Darwish, F.M.M. 2013. Phytochemical screening and HPTCL Studies of Ceiba pentandra L. Gaertn Variety pentandra Cultivied in Egypt. Journal of Pharmacognosy and Phytochemistry. Universitas Al-Azhar. Vol: 4(1).

[4] Heyne, K. 1987. Tumbuhan Berguna Indonesia. Jilid III. Cetakan I. Jakarta: Badan Litbang Kehutanan. Hal: 1312, $1543-1544$.

[5] Prasanty, A. 2014. Uji Aktivitas Anti Bakteri Ekstrak Etanolik Daun Randu (Ceiba pentandra Gaertn) Terhadap Staphylococcus epidermitis dan Shigella dysentrie. Tugas Akhir. Surakarta : FMIPA Farmasi Universitas Sebelas Maret

[6] Marchaban, Soegihardjo, C.J., dan Kumarawati, F.E. 2012. Uji Aktivitas Sari Daun Randu (Ceiba pentandraGaertn.) Sebagai Penumbuh Rambut. Jurnal Farmasi. Yogyakarta : Fakultas Farmasi UGM. Vol: 1.

[7] Purbosono, R.T. 2008. Formulasi Tablet Hisap Ekstrak Kemangi (Ocimum sanctum L.) Secara Granulasi Basah Dengan Menggunakan karboksimetilselulosa Natrium Sebagai Bahan Pengikat. Skripsi. Fakultas Farmasi Universitas Muhammadiyah Surakarta.

[8] Lachman L, Herbert A.L and Joseph I. K. 1994. Teori dan Praktek Farmasi Industri.Edisi II. Jakarta: UI Press. Hal: 643-731.

[9] Depkes RI.1989. Materia Medika Indonesia. Jilid V. Jakarta: Departemen Kesehatan RI. Hal: 254, 536-540

[10] Depkes RI. 1979. Farmakope Indonesia. Edisi III. Jakarta: Departemen Kesehatan RI. Hal: 9.

[11] Hadisoewignyo, L., dan Fudholi, A. 2013.Sediaan Solida.Yogyakarta: Pustaka Pelajar. Hal: 73-84, 114-120. 